\title{
Milk productivity and milk quality when feeding cows with si- lostan-containing haylage
}

\author{
Sergey V. Karamaev ${ }^{1, *}$, Anna S. Karamaeva ${ }^{1}$, Khaidar Z. Valitov ${ }^{1}$, Natalya V. Soboleva ${ }^{2}$, and Larisa N. Bakaeva ${ }^{2}$ \\ ${ }^{1}$ Samara State Agrarian University, 446442 Kinel, Samara Region, Russia \\ ${ }^{2}$ Orenburg State Agrarian University, 460795 Orenburg, Russia
}

\begin{abstract}
In the Middle Volga region, alfalfa is the most widely used bean fodder. In recent years, one more bean crop is used - Fodder galega. The main disadvantage of almost all legumes is low sugar content and poor haylage making abilities. To eliminate this drawback, the biological product "Silostan" was developed. It is used as a preservative. The aim of the work is to study the effect of alfalfa and Fodder galega haylage made using the bio-preservative "Silostan" on milk production and quality of milk of black and white Samara cows. The use of Silostan increased the dry matter content by 5.2 and 4.5, ECE - by 12.8 and $17.5 \%$, and digestible protein - by 27.1 and $15,5 \%$. The digestibility of dry matter increased by 3.85 and $4.38 \%$, crude protein - by 5.68 and $5.42 \%$, crude fat - by 4.26 and $5.26 \%$, crude fiber - by 3.86 and $4.07 \%$. The use of haylage with bio-preservatives increased the yield of cows for 305 days of lactation by 14.6 and $16.5 \%$. The MFF increased by 0.05 and $0.06 \%$, MFP - by 0.07 and $0.09 \%$, respectively. The technological properties of milk improved, the milk consumption per $1 \mathrm{~kg}$ of ripened cheese decreased by 4.9 and $11.2 \%$.
\end{abstract}

\section{Introduction}

Under year-round uniform feeding, silage and haylage are the most effective types of the diet. When feeding highly productive cows, the most common problem is ensuring protein needs of animals.

According to scientists, due to the existing protein deficiency, agricultural enterprises lose about $30-35 \%$ of their profits.

This problem can be solved by increasing the structure of high-protein feed crops. The decision is constrained by a limited set of bean fodder crops used in fodder production and a large difference in the natural and climatic zones in Russia [1-7].

In the Middle Volga zone, the main set of feed crops is represented by alfalfa, clover and vetch. In 1988, the Fodder galega was added to the state register of selection achievements. By its biological and fodder characteristics, Fodder galega can compete with the main proteincontaining fodder crop alfalfa; it significantly exceeds it by the productive longevity, the frost resistance, the spring regrowth rate, the green mass yield [8].

Depending on climatic conditions, soil fertility and the level of agricultural technology, the yield of fodder galega can be 70-80 tons of green mass per hectare. In one place, Fodder galega can grow for 20 years with a slight decrease in the yield.

During the year, it gives two crops without additional fertilizing. The green mass contains biologically active substances that stimulate milk secretion, stimulate the sympathetic-adrenaline system and enhance hematopoiesis, blood circulation and milk formation [9].

Its main disadvantage is low sugar content as a result of which the green mass is poorly silted. Therefore, when making haylage and silage, preservatives should be used.

For these purposes, the Institute of Microbiology of the National Academy of Sciences of the Republic of Bashortostan and BashIncom developed a number of biological preservatives; the most promising one is " $\mathrm{Si}$ lostan".

The drug is based on two strains of lactic acid bacteria Lactobacillus and a new generation veterinary probiotic which ensure aerobic stability and improve quality of feed [10-14].

The purpose of the work is to study the influence of "Silostan" on the quality of Fodder galega and alfalfa haylage, milk productivity and technological properties of milk.

\section{Methods and materials}

Research was carried out at the milk farm named after Kuybyshev, Samara region. The research object was Samara cows of black-motley breed bred by the method of reproductive crosses with Holstein bulls. The cows are kept loose-boxed (48 heads per section). Cows are fed with the same type of full-feed feed mixture - silagesilo. Haylage was made from the green mass of alfalfa and Fodder galega and dried up to $55 \%$ humidity in special trenches.

Corresponding author: KaramaevSV@mail.ru 
Alfalfa and Fodder galega, like all protein feed crops, are relatively poorly silaged due to low sugar content. In this regard, when making silage, the biological preservative Silostan was used.

The preservative was introduced using a spray gun mounted on a tractor in accordance with the recommendations of "Bashinkom" at the rate of 1 liter of the preparation per 150 tons of green mass. To feed the cows, haylage began to be used two months after laying the trans-neck.

The diet was balanced in terms of basic nutrients in accordance with detailed feeds. It included vetch hay, corn silage, alfalfa or Eastern Fodder galega haylage, concentrated feed, pa-current, premix.

Animals of group I (control) received alfalfa hay without preservatives, group II (control) - Fodder galegaa hay without preservatives, group III (experimental) alfalfa hay and group IV (experimental) - Fodder galega hay containing Silostan.

Feed quality was determined according to the generally accepted methods. The digestibility of nutrients in the body was studied by the balancing experiment method in three cows from each group.

The chemical composition of feed, feces, urine, and milk was determined in the animal husbandry research laboratory of Samara State Agrarian University and the Analytical Laboratory of Orenburg SAU using licensed equipment according to the generally accepted methods.

\section{Results}

The laboratory study of haylage samples prepared using different technologies showed that feeds have different quality (Table 1).

It was found that humidity of Fodder galega haylage made without preservatives was $1.79 \%$ lower than that of alfalfa; when the preservative was added, the difference was $2.48 \%$. At the same time, the use of the preservative reduced moisture of alfalfa haylage by $1.44 \%$, and Fodder galega haylage - by $2.13 \%$.

The bio-preservative "Silostan" consists of specially selected lactic acid bacteria that rationally use plant mass carbon stocks which can optimize the structure of organic acids.

In the haylage made with a bio preservative, the content of organic acids decreased by $0.27-0.18 \%$ due to a decrease in the fraction of acetic acid and elimination of butyric acid. The content of lactic acid increases in the alfalfa haylage by $0.04 \%$, and in the Fodder galega haylage - by $0.12 \%$.

At the same time, specific gravity of lactic acid in alfalfa hay was higher than that in Fodder galega hay by $0.43 \%$.

"Silostan" makes it possible to intensify lactic acid fermentation, optimize the ratio of organic acids, improve organoleptic properties and the nutritional value of haylage (Table 2).

Table 1. Quality of the alfalfa and fodder galega haylage

\begin{tabular}{|c|c|c|c|c|}
\hline \multirow{4}{*}{ Indicator } & \multicolumn{4}{|c|}{ Feed crop } \\
\hline & \multicolumn{2}{|c|}{ alfalfa } & \multicolumn{2}{|c|}{ Fodder galega } \\
\hline & \multicolumn{4}{|c|}{ Haylage making method } \\
\hline & preservative-free & preserved & preservative-free & preserved \\
\hline Moisture, $\%$ & 55.28 & 53.84 & 53.49 & 51.36 \\
\hline $\mathrm{pH}$ & 4.46 & 4.53 & 4.37 & 4.64 \\
\hline Content of organic acids, $\%$ : & 4.39 & 4.12 & 4.45 & 4.27 \\
\hline incl. milk & 3.49 & 3.53 & 3.52 & 3.64 \\
\hline acetic & 0.75 & 0.59 & 0.71 & 0.63 \\
\hline oil & 0.15 & - & 0.22 & - \\
\hline $\begin{array}{l}\text { The proportion of milk } \\
\text { acids to the sum of acids, } \%\end{array}$ & 79.50 & 85.68 & 79.10 & 85.25 \\
\hline
\end{tabular}

Table 2. Nutritional value of the alfalfa and fodder galega haylage

\begin{tabular}{|c|c|c|c|c|}
\hline \multirow{4}{*}{ Indicator } & \multicolumn{4}{|c|}{ Feed crop } \\
\hline & \multicolumn{2}{|c|}{ alfalfa } & \multicolumn{2}{|c|}{ Fodder galega } \\
\hline & \multicolumn{4}{|c|}{ Haylage making method } \\
\hline & preservative-free & preserved & preservative-free & preserved \\
\hline $\begin{array}{l}1 \text { kg of haylage contains: } \\
\text { dry matter, g }\end{array}$ & 446 & 469 & 465 & 486 \\
\hline feed units & 0.32 & 0.35 & 0.30 & 0.36 \\
\hline ECE & 0.39 & 0.44 & 0.40 & 0.47 \\
\hline exchange energy, MJ & 3.94 & 4.43 & 3.98 & 4.68 \\
\hline crude protein, $\mathrm{g}$ & 79.83 & 87.65 & 83.52 & 92.31 \\
\hline digestible protein, $\mathrm{g}$ & 41.62 & 52.88 & 60.24 & 69.57 \\
\hline crude fiber, $\mathrm{g}$ & 147.36 & 153.42 & 140.35 & 148.63 \\
\hline
\end{tabular}


Table 3. Digestibility of nutrients in diets composed of alfalfa and fodder galega haylage, $\%$

\begin{tabular}{|l|c|c|c|c|}
\hline \multirow{2}{*}{\multicolumn{1}{c|}{ Indicator }} & \multicolumn{4}{c|}{ Group } \\
\cline { 2 - 5 } & I & II & III & IV \\
\hline Dry matter & $64.33 \pm 0.59$ & $68.84 \pm 0.62$ & $68.18 \pm 0.56^{* *}$ & $73.22 \pm 0.51^{* *}$ \\
\hline Organic matter & $69.21 \pm 0.65$ & $72.12 \pm 0.57$ & $72.54 \pm 069^{*}$ & $75.43 \pm 0.66^{*}$ \\
\hline Crude protein & $67.94 \pm 0.43$ & $71.96 \pm 0.56$ & $73.62 \pm 0.52^{* * *}$ & $77.38 \pm 0.63^{* *}$ \\
\hline Crude fat & $62.48 \pm 0.54$ & $59.31 \pm 0.62$ & $66.74 \pm 0.68^{* *}$ & $64.57 \pm 0.56^{* *}$ \\
\hline Crude fiber & $51.63 \pm 0.67$ & $56.27 \pm 0.49$ & $55.49 \pm 0.59^{* *}$ & $60.34 \pm 0.55^{* *}$ \\
\hline NVES & $73.56 \pm 0.48$ & $72.69 \pm 0.53$ & $81.46 \pm 0.57 * * *$ & $79.92 \pm 0.61^{* * *}$ \\
\hline
\end{tabular}

Note: $* \mathrm{P}<0,05 ; * * \mathrm{P}<0,01 ; * * * \mathrm{P}<0,001$

Table 4. Milk productivity of cows (lactation III)

\begin{tabular}{|l|c|c|c|c|}
\hline \multirow{2}{*}{ Indicator } & \multicolumn{4}{c|}{ Group } \\
\cline { 2 - 5 } & I & II & III & IV \\
\hline Duration of lactation, days & $354.6 \pm 8.12$ & $349.2 \pm 6.74$ & $331.5 \pm 7.34$ & $326.9 \pm 7.68$ \\
\hline Milk yield for 305 days of lactation, kg & $5049 \pm 123.84$ & $5264 \pm 146.33$ & $5786 \pm 112.47 * * *$ & $6132 \pm 129.56^{* * *}$ \\
\hline Milk yield, kg & $5436 \pm 125.47$ & $5640 \pm 149.26$ & $6014 \pm 115.63 * * *$ & $6358 \pm 130.81^{* * *}$ \\
\hline MFF, \% & $3.69 \pm 0.03$ & $3.72 \pm 0.02$ & $3.74 \pm 0.01$ & $3.78 \pm 0.02$ \\
\hline Milk fat, kg & $186.31 \pm 4.72$ & $195.82 \pm 3.59$ & $216.40 \pm 4.11$ & $231.79 \pm 4.33$ \\
\hline MFP, \% & $3.11 \pm 0.02$ & $3.15 \pm 0.02$ & $3.18 \pm 0.01 * * *$ & $3.24 \pm 0.01^{* * *}$ \\
\hline Milk protein, kg & $157.02 \pm 4.24$ & $165.82 \pm 4.65$ & $183.99 \pm 3.82$ & $198.68 \pm 4.14$ \\
\hline Live weight kg & $541.4 \pm 5.98$ & $539.8 \pm 4.47$ & $548.6 \pm 5.23$ & $552.1 \pm 4.96$ \\
\hline Milk index & $932.6 \pm 18.71$ & $975.2 \pm 16.94$ & $1054.7 \pm 17.30^{* * *}$ & $1110.7 \pm 18.45^{* * *}$ \\
\hline Milk per 1 day of lactation, $\mathrm{kg}$ & $15.33 \pm 0.69$ & $16.15 \pm 0.852$ & $18.14 \pm 0.47 * * *$ & $19.45 \pm 0.59^{* * *}$ \\
\hline
\end{tabular}

Note: $* * * \mathrm{P}<0,001$

Due to the use of Silostan, the dry matter content in the alfalfa haylage increased by $5.2 \%$, in the Fodder galega haylage increased by $4.5 \%$; energy feed units (EFU) increased by 12.8 and $17.5 \%$, respectively; crude protein - by 9.8 and $10.5 \%$, digestible protein - by 27.1 and $15.5 \%$, crude fiber - by 4.1 and $5.9 \%$, respectively.

It should be noted that the nutritional value of Fodder galega haylage was higher in terms of dry matter content by $3.6 \%$, EFU - by $6.8 \%$, crude protein - by $5.3 \%$, digestible protein - by $31.6 \%$; the content of crude fiber decreased by $3.1 \%$.

The balance experiment conducted on full-aged cows during the 2-3 months of lactation showed that Fodder galega haylage with a bio-preservative was better digested than alfalfa one (Table 3).

It was found that a bioconservative added to the alfalfa haylage sincreased the digestibility of dry matter by $3.85 \%(\mathrm{P}<0.01)$, organic matter - by $3.33 \%(\mathrm{P}<0.05)$, raw protein - by $5.68 \%(\mathrm{P}<0.001)$, crude fat - by $4.26 \%$ $(\mathrm{P}<0.01)$, crude fiber - by $3.86 \%(\mathrm{P}<0.01)$, NVES - by $7,9 \%(\mathrm{P}<0.001)$; a bioconservative added to the Fodder galega haylage increased these indicators by $4.38 \%$ $(\mathrm{P}<0.01) ; 3.31 \% \quad(\mathrm{P}<0.05) ; 5.42 \% \quad(\mathrm{P}<0.01) ; \quad 5.26 \%$ $(\mathrm{P}<0.01)$; by $4.07 \%(\mathrm{P}<0.01) ; 7.23 \%(\mathrm{P}<0.001)$, respectively.

At the same time, digestibility of dry matter of the Fodder galega diet was $5.04 \%(\mathrm{P}<0.01)$ higher, the content of organic matter was $2.89 \%$ higher $(\mathrm{P}<0.05)$, crude protein $-3.76 \%$ higher $(\mathrm{P}<0.01)$, crude fiber $-4.85 \%$ higher $(\mathrm{P}<0.01)$; the digestibility of raw fat was lower by $2.17 \%$, NVES - by 1.54 .
Higher quality and nutrition value of haylage containing the bio preservative, its better digestibility made it possible to increase the level of milk productivity of cows of the experimental groups (Table 4).

When feeding cows with Fodder galega hay, the milk yield was higher by $215 \mathrm{~kg}(4.3 \%)$ in comparison with alfalfa hay lacking Silostan, and by $346 \mathrm{~kg}(6,0 \%$; $\mathrm{P}<0.05)$ in comparison with alfalfa hay containing Silostan.

When Silostan was added to the sowing alfalfa mass, the milk yield increased by $737 \mathrm{~kg}(14.6 \%$; $\mathrm{P}<0.001)$; when Silostan was added to the sowing Fodder galega mass, the milk yield increased by $868 \mathrm{~kg}$ (16.5\%; $\mathrm{P}<0.001)$.

Along with an increase in the milk yield, quality of milk improved as well. The mass fraction of fat increased by 0.05 and $0.06 \%$, the mass fraction of protein increased by 0.07 and $0.09 \%$, respectively $(\mathrm{P}<0.001)$.

In cows, consumption of haylage with a biopreservative increased the intensity of milk synthesis. For every $100 \mathrm{~kg}$ of live weight (milk index), the milk yield gain was $122.1 \mathrm{~kg}$ per cow $(13.1 \%$; $\mathrm{P}<0.001)$ when feeding with alfalfa and $135.5 \mathrm{~kg}(13.9 \%$; $\mathrm{P}<0.001)-$ when feeding with Fodder galega.

Thus, per 1 day of lactation, the milk yield in cows of group III was higher than that in cows of group I by 2.81 $\mathrm{kg}(18.3 \%$; $\mathrm{P}<0.001)$; the milk yield in cows of group IV was higher than that in cows of group II by $3.3 \mathrm{~kg}$ $(20.4 \% ; \mathrm{P}<0.001)$.

Evaluation of technological properties of milk showed that feeding with Silostan-containing haylage had a positive effect on cheese suitability (Table 5). 
Table 5. Technological properties of milk in the production of hard cheese

\begin{tabular}{|c|c|c|c|c|}
\hline \multirow{2}{*}{ Indicator } & \multicolumn{4}{|c|}{ Group } \\
\hline & $\mathrm{I}$ & II & III & IV \\
\hline Duration of coagulation with rennet, min & $41.3 \pm 2.35$ & $39.6 \pm 1.94$ & $34.2 \pm 1.67 *$ & $31.9 \pm 2.12 *$ \\
\hline including coagulation phase, min & $31.5 \pm 1.83$ & $30.2 \pm 0.98$ & $26.8 \pm 1.29$ & $24.8 \pm 1.36$ \\
\hline gel formation phase, $\min$ & $9.8 \pm 0.67$ & $9.4 \pm 0.82$ & $7.4 \pm 0.52$ & $7.1 \pm 0.48$ \\
\hline The duration of rennet processing, $\min$ & $60.8 \pm 2.98$ & $58.7 \pm 3.24$ & $54.6 \pm 3.01$ & $53.3 \pm 2.73$ \\
\hline Dry whey waste, $\%$ & $55.3 \pm 0.69$ & $54.1 \pm 0.55$ & $53.4 \pm 0.46$ & $51.7 \pm 0.49$ \\
\hline The ratio of fractions rennet: serum, $\%$ & $29: 71$ & $30: 70$ & $34: 66$ & $35: 65$ \\
\hline The density of rennet, $\mathrm{g} / \mathrm{cm}^{2}$ & $2.10 \pm 0.01$ & $2.28 \pm 0.02$ & $2.53 \pm 0.01$ & $2.72 \pm 0.02$ \\
\hline Moisture holding ability, $\%$ & $55.8 \pm 0.34$ & $57.3 \pm 0.41$ & $59.9 \pm 0.27$ & $61.5 \pm 0.30$ \\
\hline Consumption of whole milk per $1 \mathrm{~kg}$ of ripe cheese, $\mathrm{kg}$ & $12.2 \pm 0.43$ & $11.6 \pm 0.39$ & $10.8 \pm 0.31 *$ & $10.3 \pm 0.37 *$ \\
\hline
\end{tabular}

Note: $* \mathrm{P}<0,05$

In the cows of the experimental groups, the duration of milk coagulation was reduced when exposed to rennet by $7.1 \quad(17.2 \% ; \mathrm{P}<0.05)$ and 7.7 minutes $(19.4 \%$; $\mathrm{P}<0.05)$. The duration of the casein rennet treatment was also reduced by $6.2(10.2 \%)$ and $5.4 \mathrm{~min}(9.2 \%)$. Improvement of the technological properties and chemical composition of milk reduced the loss of nutrients. At the same time, the rennet: serum ratio improved due to an increase in the rennet share in the experimental samples by $5 \%$.

Quality of rennet and its density are crucial in the production of hard cheese. In accordance with technical conditions, density of the rennet should be $2.7-3.5 \mathrm{~g} / \mathrm{cm}^{2}$. It was established that only including Silostan in the diet, quality of the rennet corresponded to the minimum requirements $\left(2.72 \mathrm{~g} / \mathrm{cm}^{2}\right)$.

Improving the technological properties of milk made it possible to reduce the production cost of $1 \mathrm{~kg}$ of ripened cheese by $1.4(11.5 \%$; $\mathrm{P}<0.05)$ and $1.3 \mathrm{~kg}(11.2 \%$; $\mathrm{P}<0.05)$.

\section{Conclusion}

It was found that the use of Silostan at the rate of 1 liter of the preparation per 150 tons of green mass improves organoleptic characteristics and the nutritional value of the feed. Feeding lactating cows with Fodder galega haylage containing Silostan improved digestibility of nutrients due to the higher leafiness of Fodder galega compared to alfalfa. As a result, milk productivity of cows per 1 day of lactation increased due to the biological characteristics of Fodder galega by $5.3 \%$, due to the introduction of Silostan - by $20.4 \%$. At the same time, the technological properties of milk improved, milk consumption per $1 \mathrm{~kg}$ of ripened cheese decreased by 4.9 $11.2 \%$.

\section{References}

1. F.S. Khaziakhmetov, A.F. Khabirov, R.Kh. Avzalov, G.R. Tsapalova, M.B. Rebezov, Kh.Kh. Tagirov, Sh.Sh. Giniyatullin, Kh.G. Ishmuratov, G.S. Mishukovskaya, F.M. Gafarova, Zh.S. Yessimbekov, Effect of probiotics on calves, weaned pigs and lamb growth Research J. of Pharmaceutical, Biological and Chemical Sciences 9(3), 866-870 (2018)
2. F.S. Khaziakhmetov, A.F. Khabirov, R.Kh. Avzalov, G.R. Tsapalova, M.B. Rebezov, Kh.Kh. Tagirov, Sh.Sh. Giniyatullin, Kh.G. Ishmuratov, G.S. Mishukovskaya, F.M. Gafarova, Zh.S. Esimbekov, Valuable effect of using probiotics in poultry farming Annual Research \& Review in Biology 25(1), 1-7 (2018)

3. L.P. Zaripova, F.S. Gibadullina, Sh.K. Shakirov et al., Feed of the Republic of Tatarstan: composition, nutrition and use 272 (Foliant, Kazan, 2010)

4. Z.N. Sheigratsova, A.F. Trofimov, The dynamics of humoral indicators of calves with the application of a compiex of biologacalli active substances Current problems of intensive development of animal nusbanbry, 343-349 (Gorki, 2012)

5. D.R. Davies, R. Fychan, R. Jones, Aerobic deterioration of silage: causes and controls in Nutritional Biotechnology in the feed and Food Industries. Proc. of All tech's 23rd Annual Symposium 227-238 (Nottingham, 2007)

6. C.D. Ellermeier, E.C. Hobbs, J.E. Gonzales et al., A Three-Protein Signaling Pathway Governing Immunity to Bacterial Cannibalism Toxin Cell 124, 549-559 (2006)

7. E. Streit, G. Schatzmayr, P. Tassis, E. Tzika, D. Marin, I. Taranu, C. Tabuc, A. Nicolau, I. Aprodu, O. Puel, I.P. Oswald, Current situation of mycotoxin contamination and co-occurrence in animal feed focus on Europe Toxins 4(10), 788-809 (2012)

8. S. V. Karamaev, L. N. Bakaeva, Kh. Z. Valitov, V. P. Lushnikov, M. V. Zabelina, N. G. Chamurliev, A. S. Karamaeva, Quality of colostrum milk of large cattle dairy breeds Research J. of Pharmaceutical, Biological and Chemical Sciences 9(5), 1429-1439 (2018)

9. V.I. Levakhin, E.A. Azhmuldinov, M.G. Titov, Yu.A. Lasygina, The effect of forage from eastern goatskin and alfalfa on meat productivity and biological value of meat of gobies of Simmental breed Feed production 10, 40-44 (2014)

10. Yu.A. Pobednov, I.V. Kuchin, V.V. Soldatov, Comparative efficiency of silage cultivation and silage of dried cereal grasses with preparations of lactic acid bacteria Feed production 3, 36-40 (2016)

11. A.T. Varakin, V.V. Salomatin, Milk productivity of cows when feeding alfalfa silage harvested using a 
new preservative News of the Lower Volga AgroUniversity Complex: science and higher professional education 2, 90-94 (2012)

12. O.A. Kinsfator, The effectiveness of using Biotrof 111 when harvesting haylage in film packaging for feeding lactating cows Bulletin of Novosibirsk State Agrarian University 2(43), 129-135 (2017)
13. V.P. Klimenko, V.M. Kosolapov, A.V. Logutov, The use of biological products for producing silage and haylage from legumes Zootechny 1, 12-15 (2017)

14. H.H. Tagirov, F.F. Vagapov, N.V. Gizatova, Quality of tanning raw material when feeding to probiotic gobies News of Science and Education 1(3), 27-29 (2018) 